\title{
The Effect of Product Quality, Brand Image, and Halal Labeling on Purchase Decisions with Purchase Intentions as Intervening Variables
}

\author{
Ary Dewi Saputri ${ }^{1}$, Agung Guritno ${ }^{1}$ \\ ${ }^{1}$ Faculty Of Islamic Economics And Business, IAIN Salatiga, Indonesia
}

\begin{abstract}
This research is motivated by the great potential in Boyolali Regency, Central Java, in the field of cow's milk production and its processed products. The purpose of this study was to determine the factors that influence purchasing decisions for Indrakila Cheese products in Boyolali, Central Java. The research method used is quantitative research with purposive random sampling technique. The data analysis used includes instrument test, multiple linear regression analysis, statistical test, classical assumption test and path analysis. The results of this study indicate that the variables of product quality, brand image, halal labeling, and purchase intention simultaneously have a positive and significant influence on purchasing decisions. Partially product quality and brand image have a significant positive effect on purchase intention, but halal labeling has no effect on purchase intention. The results of the path analysis test show that there is mediation between product quality, brand image, and purchase intention on purchasing decisions, but cannot mediate between halal labeling on purchasing decisions.
\end{abstract}

Keywords: product quality, brand image, halal labelling, purchase intention, purchase decision

\section{Introduction}

Boyolali Regency is one of the largest and most productive cow's milk producing areas in Central Java Province. Because of the abundance of milk it produces, Boyolali has been known as the City of Milk. There are four areas in Boyolali Regency that produce very productive cow's milk, including: Boyolali District, Musuk District, Cepogo District and Mojosongo District (Parmawati, 2019).

Seeing the potential in Boyolali Regency, triggers a young man to innovate in milk processing. In 2009 in Boyolali Regency there was a young man who graduated from UMS (University of Muhammadiyah Surakarta) named Noviyanto. Noviyanto has initiated that in Boyolali it is not only synonymous with milk, but is followed by the diversity of creations in the management of pure milk into ready-to-eat products, namely Indrakila cheese (Juliati, 2019). The resulting cheese has a variety of taste images that are not inferior to foreign-made cheeses. Currently Indrakila cheese has 8 types of cheese, namely : fresh mozzarella cheese, yellow mozzarella cheese, original mountain cheese, mountain chili cheese, olive oil feta cheese, blackpaper feta cheese, chili feta cheese, and boyobert cheese. 


\section{$A I C B$ Annual International Conference \\ on Islamic Economics and Business 2021}

Table 1. Dairy Cow Milk Revenue and Sales Data on 2019

\begin{tabular}{|c|c|c|}
\hline Districs & Acceptance of KUD & Factory Sales \\
\hline Cepogo & 7.300 .000 liter & 6.935 .000 liter \\
\hline Musuk & 11.680 .000 liter & 11.096 .000 liter \\
\hline Boyolali & 6.570 .000 liter & 6.241 .500 liter \\
\hline Mojosongo & 16.425 .000 liter & 15.603 .750 liter \\
\hline Total & 41.972 .000 liter & 39.876 .250 liter \\
\hline
\end{tabular}

Source: data processed by BPS 2019

McCarthy in Nafilah et al. (2019) defines purchase intention in a product as an intention that arises in a person to make a purchase on a product, where the product is considered to be able to meet the needs of its consumers. The company certainly has a goal to fulfill a consumer's wants and needs. This statement is relevant to the observations made by Wicaksono (2016), explaining that the purchase intention variable has a positive and significant influence on purchasing decisions.

Purchasing decision is a determining stage for someone in buying the desired product. Before making a decision, consumers have done several stages of analysis to determine their decision. This statement is in line with the opinion conveyed by Peter and Olson in Siregar (2018) which states that "the essence of purchasing decision making is an integration process that combines consumer knowledge that can be used to evaluate between two or more behaviors, by selecting one of them".

One thing that consumers pay attention to before making a purchase on a product is to see the quality of the product. Product quality is the ability of the product to perform its function, it is in the form of overall durability, reliability, accuracy, ease of operation and product repair or other product attributes (Kotler \& Amstrong, 2008). Consumers can judge the product well, when the quality of the product is in accordance with the wishes of the consumer and the consumer likes it. In this case, the company must be able to provide highquality products to consumers, and can provide different qualities from other products that have been marketed. When the company manages to maintain product quality as well as possible, consumers will always maintain purchase intention in the product as long as the product is considered good and can meet consumer needs (Kotler \& Amstrong, 2008). Based on previous research, there are inconsistencies in the results of product quality variables. Research conducted by (Khuri, 2020) shows that product quality variables have a positive influence on purchasing decisions. Meanwhile, research conducted by Kharisma \& Hutasuhut (2019) showed that the product quality variable had no effect on purchasing decisions.

Internal and external factors can also encourage someone in determining a purchase decision is the brand image. Brand is something that is attached to the product. Image is the impression that consumers build on a particular brand. A positive image of the brand will have an impact in the form of purchasing actions against the brand. Thus, brand image is a set of associations of a brand that is already attached to consumers (Rangkuti, 2004). Based on previous research, there are inconsistent results in the brand image variable. According to Kurniawan (2018) and Saputra (2018), it shows that the brand image variable has a positive influence on purchasing decisions. Meanwhile, according to Lubis (2017) it shows that the brand image variable has no effect on purchasing decisions. 


\section{$A I \overline{I E B} \quad$ Annual International Conference \\ on Islamic Economics and Business 2021}

The next thing that can influence consumer decision making is halal labeling. The halalness of a product is the main factor that becomes a person's attention before making a purchase decision. Considering the majority of the Indonesian population is Muslim, producers must be able to understand the lifestyle of the Muslim community. Muslims are required to always maintain the halal aspect of the products to be consumed. Based on previous research, there are inconsistencies in the results in the halal labeling variable. According to Immamuddin (2017) also Alim et al. (2018), it shows that there is a positive and significant influence on the halal label variable on purchasing decisions. Meanwhile, according to Alfian \& Marpaung (2017) shows that the halal label has a negative effect on purchasing decisions.

Based on the theoretical description above, there are still differences in research results in the variables of product quality, brand image, halal labeling, purchasing decisions, and purchase intention. Therefore, the author wants to explore further about the problem above with the title The Effect of Product Quality, Brand Image, and Halal Labeling on Purchase Decisions for Indrakila Cheese with Purchase Intention as an Intervening Variable (Case Study of Consumers for Indrakila Boyolali Cheese Products).

\section{Literature Review}

\subsection{Theory of Planned Behavior (TPB)}

The Theory of Planned Behavior (TPB) is a theory developed from Theory Reasoned Action (TRA) by Icek Ajzen and Martin Fishbein in 1967. In 1988 an existing reasoned action model was added, and later this theory was named Theory of Planned Behavior (Mahyarni, 2013). TPB is a theory that describes the desire (interest) of individuals to take certain actions or activities (Sukmaningrum \& Rahardjo, 2017). The theory of planned behavior, reveals that there are three things that become antecedents of intentions that affect a person's behavior in the future (Widarjo et al., 2014). Thus, this theory has three independent factors. First is attitude towards behavior, second is social factor or subjective norm, and third is control behavior factor. This theory is suitable for explaining any behavior that requires planning (ajzen, 1991).

\subsection{Product Quality}

\subsubsection{Definition of Product Quality}

According to (Kotler \& Amstrong, 2004) product quality is the product's ability to perform its functions such as durability, reliability, consistency, convenience and other attributes. If the product can carry out its function, then the product can be said to have good product quality. Product quality is commonly used by companies as a strategic weapon in sales, where the weapon is to beat competitors in the market. A product can be said to have good quality or high quality, if the product can meet the needs and desires of consumers.

\subsubsection{Product Quality Influence Factors}

According to (Tjiptono, 2008) there are four factors that can affect product quality, including:

1) Design on products and services, there are types of products whose quality is influenced by the product itself. 


\section{$A I C \overline{I E B}$ Annual International Conference \\ on Islamic Economics and Business 2021}

2) The type of raw material used, the most influential factor is the material used for the basic material for the manufacture of a particular product.

3) Tools for producing goods. Technology is an important point in the manufacturing process, because this can affect the quality of the products it produces.

4) Packaging Delivery. Paying attention to the packaging and delivery of products, is the most important thing for the company. Because if the delivery and packaging is carried out properly, of course a buyer will receive the product in good condition or there is no product damage.

\subsubsection{Product Quality Indicators}

The quality of a product can be identified through several indicators, including the following (Indriyo, 2014):

1) There are several types of products.

2) Have a good product durability, namely how long the product can continue to be consumed.

3) Have product quality according to consumer specifications.

4) Have an attractive appearance on the product packaging.

5) Have good product quality from other brands.

\subsection{Brand Image}

\subsubsection{Definition of Brand Image}

According to (Kotler \& Keller, 2009) brand image is a consumer trust that is already contained in the consumer's memory, which is always remembered by the consumer. A product has a good value, if there is a brand attached to the product through the assessment of a buyer. If the product already has a brand, then the product has benefits, namely making it easier to search for a company, and for consumers to be used as a benchmark in measuring how much satisfaction with the product (Tjiptono, 2008).

\subsubsection{Brand Image Factors}

According to (Kotler, 2000) there are two main factors of brand image, namely:

1) The first factor in brand image is the physical factor, this factor is a characteristic of the brand, including: product design, product packaging, logo on the product, brand on the product, function and use of the product on the brand

2) The second factor is psychological factors, these psychological factors can be formed by consumer beliefs that can describe the product in the brand.

\subsubsection{Brand Image Indicators}

According to (Kotler \& Keller, 2013) indicators on brand image include:

1) Consumer perception of a brand

This perception is an added value that is embedded in a product brand, through what has been seen, heard, learned and the experience of consumers towards the product brand.

2) Consumer confidence in a brand 


\section{$A \mathrm{I} \overline{I E B}$ Annual International Conference \\ on Islamic Economics and Business 2021}

This is a form of consumer trust that has been attached to consumer memory. This perception is in the form of past experiences of consumers as well as information about brands on certain products.

3) Brand association

Brand associations are various forms of customer memory on a particular brand. According to (Kotler \& Keller, 2013), brand association is the main form of brand image formation, where brand image will be used as the basis for consumers to make a purchasing decision for a product.

\subsection{Halal Labeling}

\subsubsection{Definition of Halal Labeling}

The label is something that is owned by the product in the form of a notification which is usually placed on the product packaging in the form of detailed writing. Halal is all activities that are allowed to be carried out. So, what is meant by halal labeling is to provide a clear written halal sign, used to show that the product is halal for consumption by the general public.

\subsubsection{Halal Labeling Indicators}

The indicators contained in halal labeling including (Latiff et al., 2016) :

1) There is a halal logo, a halal logo from MUI which is printed on the packaging of a product with the aim that Muslim consumers can recognize halal products.

2) There is a composition label, with the composition on a product having the aim that consumers can know the ingredients it uses.

3) There is a nutritional content label, this aims to determine the amount of nutritional content contained in a product.

\subsection{Purchase Intention}

\subsubsection{Definition of Purchase Intention}

Intention is the initial process of feeling in one's heart in starting an activity from a business which is usually long-term (Yadewani \& Wijaya, 2017). Purchase intention is a desire to encourage someone to buy a product to meet their needs (Cannon, 2009).

\subsubsection{Purchase Intention Factors}

Several things can influence someone to buy a product, including:

1) Knowledge, knowledge is a benchmark from someone who has done sensing on a product, which makes that person find what has been obtained. Knowledge here can be obtained through education, media and the environment.

2) Information, information is the result of a search for useful data for the recipient, where the information can describe actual events, which can be used as purchasing decisions.

3) Experience, experience here is a way of obtaining a truth that is done, namely by repeating what has been obtained in solving problems faced in the past. 


\section{$A I \overline{I F B}$ Annual International Conference \\ on Islamic Economics and Business 2021}

\subsubsection{Purchase Intention Indicators}

The indicators on purchase intention include (Kinnear and Taylor, in (Suyono \& Sri, 2012):

1) Interest, being interested in a product can be shown by the presence of someone's feelings of pleasure in a product being offered.

2) Desire, when consumers are interested in products that match their desires, what consumers will do is to have the product.

3) Confidence, confidence will arise when consumers have confidence in a product. It can be proven by believing in the quality of the product and the usability of the product.

\subsection{Purchase Decision}

\subsubsection{Definition of Purchase Decision}

According to (Kotler \& Amstrong, 2008) purchase decision is the action of a customer when he wants to buy or not on a product offered by the company. That is, the purchase decision is an action that is tried by a customer before and after buying after selecting the goods to be purchased. According to (Kotler \& Amstrong, 2004) there are several stages of decision making that must be passed by the buyer, namely:

1) Need Recognition (Introduction to a problem in a need)

In purchasing a product, of course, consumers are aware that there are problems and needs when they buy a product. Consumers must be able to understand the difference between the actual state and the desired state.

2) Information search

Before making a purchase on a product, of course, consumers will dig up information from various sources about the product they are interested in. Thus, companies are required to be able to find the main sources of information needed by consumers and must be able to attract their interest in determining purchasing decisions.

3) Evaluation of alternatives

The next stage is alternative evaluation, where consumers evaluate brand selection from choice to finally buy the product. Consumers can choose products based on what they want and which can meet their needs.

4) Purchase decision

Consumers will form preferences among the various brands encountered in the group of choice. If consumers choose to buy a product, then consumers have several considerations that must be considered when making decisions, including paying attention to the quality of the product, the brand in the product, the seller's side, location, the price of the product offered, etc.

5) Postpurchase behavior

After going through many stages, consumers will evaluate the selected option, whether it meets the needs or not. When the product meets their needs, consumers decide to take a stand, namely by using the product they buy as a way for consumers to attract market attention.

\subsubsection{Purchase Decision Indicators}

The indicators of this variable, according to (Kotler \& Keller, 2007), are divided into 4, namely: 


\section{$A \mathrm{IC} \overline{I E B}$ Annual International Conference \\ on Islamic Economics and Business 2021}

1) Product stability, meaning that if the product is of high quality, it will increase consumer confidence, so as to create customer satisfaction and loyalty.

2) Buying habits, consumers will continue to buy similar goods if they believe that the goods can meet their needs.

3) Provide recommendations to others, if a consumer gets satisfaction from the product purchased, of course they will recommend it to others.

4) Repurchase, namely when consumers feel comfortable with the product purchased, so that it can influence consumers to repurchase the product.

\section{Research Method}

This research is quantitative research using primary data. The population in this study were consumers of Indrakila Boyolali cheese. Research whose population is unknown can be calculated using the Wibisono sample formula in (Akdon \& Riduwan, 2013). In this study it can be calculated by applying the formula:

$$
\mathrm{n}=\left(\frac{\frac{z a}{2} \cdot o^{\prime}}{\varepsilon}\right)^{2}
$$

Descriptions:

$\mathrm{n} \quad=$ number of samples

$\frac{Z a}{2}=$ the level of confidence at a significant level of $5 \%$ is 1.96

$\sigma^{\circ} \quad=$ population standard deviation of 0.25

$\mathcal{E}=$ margin of error of 0,05

To find out consumer samples for Indrakila Cheese products, it can be calculated as follows:

$$
\begin{array}{ll}
\mathrm{n} & =\left(\frac{\frac{z a}{2} \cdot \mathrm{o}^{\prime}}{\varepsilon}\right)^{2} \\
\mathrm{n} & =\left(\frac{1,96 \cdot 0.25}{0,05}\right)^{2} \\
\mathrm{n} & =96,04
\end{array}
$$

With the above calculation the number of samples obtained is 96.04 samples, then rounding is done to 100 samples. So this study used a sample of 100 , consisting of consumers of Indrakila cheese products.

\section{Discussion}

\subsection{Instrument Test}

\subsubsection{Validity Test}

Validity test serves to determine whether a questionnaire is valid or not in the study. To find out the questionnaire in this study, it can be seen in the following table: 
Table 2. Validity Test Result

\begin{tabular}{|c|c|c|c|c|}
\hline No & Variable & Question & r Count & Description \\
\hline \multirow[t]{5}{*}{1} & \multirow{5}{*}{$\begin{array}{l}\text { Product Quality } \\
\left(\mathrm{X}_{1}\right)\end{array}$} & Element 1 & $0.784(* *)$ & Valid \\
\hline & & Element 2 & $0.893(* *)$ & Valid \\
\hline & & Element 3 & $0.664(* *)$ & Valid \\
\hline & & Element 4 & $0.875(* *)$ & Valid \\
\hline & & Element 5 & $0.878(* *)$ & Valid \\
\hline \multirow[t]{3}{*}{2} & \multirow{3}{*}{$\begin{array}{l}\text { Brand Image } \\
\left(\mathrm{X}_{2}\right)\end{array}$} & Element 1 & $0.810(* *)$ & Valid \\
\hline & & Element 2 & $0.890(* *)$ & Valid \\
\hline & & Element 3 & 0.939 (**) & Valid \\
\hline \multirow[t]{3}{*}{3} & \multirow{3}{*}{$\begin{array}{l}\text { Halal Labeling } \\
\left(\mathrm{X}_{3}\right)\end{array}$} & Element 1 & $0.804(* *)$ & Valid \\
\hline & & Element 2 & $0.835(* *)$ & Valid \\
\hline & & Element 3 & $0.866(* *)$ & Valid \\
\hline \multirow[t]{3}{*}{4} & \multirow{3}{*}{$\begin{array}{l}\text { Purchase } \\
\text { Intention (Z) }\end{array}$} & Element 1 & 0.839 (**) & Valid \\
\hline & & Element 2 & $0.788(* *)$ & Valid \\
\hline & & Element 3 & $0.768(* *)$ & Valid \\
\hline \multirow[t]{4}{*}{5} & \multirow{4}{*}{$\begin{array}{l}\text { Purchase } \\
\text { Decision (Y) }\end{array}$} & Element 1 & $0.750(* *)$ & Valid \\
\hline & & Element 2 & $0.805(* *)$ & Valid \\
\hline & & Element 3 & $0.825(* *)$ & Valid \\
\hline & & Element 4 & $0.715(* *)$ & Valid \\
\hline
\end{tabular}

Source: primary data processed, 2021

According to table 2 above, it was found that the question element was valid and could function for the test model. By proving that all sentences from each indicator show 2 stars $(* *)$ which indicates that the significance is at the $5 \%$ or 0.05 level.

\subsubsection{Reliability Test}

Reliability test is to test the consistency of measurement from one respondent to another. The goal is to measure the reliability of the measuring instrument used. The following are the results of the reliability test obtained in the study: 
Table 3. Reliability Test Result

\begin{tabular}{|c|l|c|c|}
\hline No & \multicolumn{1}{|c|}{ Variable } & $\begin{array}{r}\text { Cronbach's } \\
\text { Alpha }\end{array}$ & Description \\
\hline 1 & Product Quality $\left(\mathrm{X}_{1}\right)$ & 0.879 & Reliable \\
\hline 2 & Brand Image $\left(\mathrm{X}_{2}\right)$ & 0.855 & Reliable \\
\hline 3 & Halal Labeling $\left(\mathrm{X}_{3}\right)$ & 0.778 & Reliable \\
\hline 4 & Purchase Intention $(\mathrm{Z})$ & 0.698 & Reliable \\
\hline 5 & Purchase Decision $(\mathrm{Y})$ & 0.775 & Reliable \\
\hline
\end{tabular}

Source: primary data processed, 2021

From the data in table 3 above, it shows that each variable has a Cronbach alpha value $>0.6$. So, all the elements of the question on each of the research variables are reliable. Then all elements of the question can be trusted and can be used for further research

\subsection{Statistic Test}

\subsubsection{T Test (Individul Test)}

The $t$ test serves to determine the level of significance of the independent variables that have an influence on the dependent variable individually or collectively (Ghozali, 2011). The following are the results of the t-test in this study:

Table 4. T Statistic Results (T test 1 )

\begin{tabular}{|c|c|c|c|c|c|c|}
\hline \multicolumn{7}{|c|}{ Coefficients $^{\mathbf{a}}$} \\
\hline \multirow{2}{*}{\multicolumn{2}{|c|}{ Model }} & \multicolumn{2}{|c|}{$\begin{array}{l}\text { Unstandardized } \\
\text { Coefficients }\end{array}$} & \multirow{2}{*}{$\begin{array}{l}\begin{array}{l}\text { Standardized } \\
\text { Coefficients }\end{array} \\
\text { Beta }\end{array}$} & \multirow[t]{2}{*}{$\mathrm{t}$} & \multirow[t]{2}{*}{ Sig. } \\
\hline & & B & Std. Error & & & \\
\hline \multirow[t]{5}{*}{1} & (Constant) & 3.228 & .887 & & 3.637 & .000 \\
\hline & $\begin{array}{c}\text { Produk Quality } \\
\text { (X1) }\end{array}$ & .159 & .062 & .247 & 2.553 & .012 \\
\hline & Brand Image (X2) & .349 & .108 & .314 & 3.233 & .002 \\
\hline & Halal Labeling(X3) & .219 & .090 & .184 & 2.429 & .017 \\
\hline & $\begin{array}{l}\text { Purchase Intention } \\
\text { (Z) }\end{array}$ & .259 & .118 & .215 & 2.196 & .030 \\
\hline & endent Variable : & hase & ecision $(\mathrm{Y})$ & & & \\
\hline
\end{tabular}

Source: primary data processed, 2021

According to table 4 above, it can be seen from the probability value of the significance of each variable, it can be concluded as follows :

1) The quality of the product has a t-count value of 2.553 , and a significance value of 0.012 . The significance value is $0.012<0.05$, then $\mathrm{H} 0$ is rejected, so it can be interpreted if the quality of the product has an influence on purchasing. 


\section{$A I C \overline{I E B}$ Annual International Conference \\ on Islamic Economics and Business 2021}

2) Brand image has a t-count value of 3.233 and a significance value of 0.002 . The significance value is $0.002<0.05$, then $\mathrm{H} 0$ is rejected, so it can be interpreted that brand image has an influence on purchasing decisions.

3) Halal labeling has a t-count value of 2,429 and a significance value of $0.017 .<0.05$. The significance value is $0.017<0.05$, then $\mathrm{H} 0$ is rejected, so it can be interpreted if halal labeling has an influence on purchasing decisions.

4) Purchase interest has a t-count value of 2.196 and a significance value of 0.030 . The significance value is $0.030<0.05$, then $\mathrm{HO}$ is rejected, so it can be interpreted that purchase intention has an influence on purchasing decisions.

Table 5. Partial Effects of Statistical Test Results (T test 2)

\begin{tabular}{|c|c|c|c|c|c|c|}
\hline \multicolumn{7}{|c|}{ Coefficients $^{\mathrm{a}}$} \\
\hline \multirow{2}{*}{\multicolumn{2}{|c|}{ Model }} & \multicolumn{2}{|c|}{$\begin{array}{l}\text { Unstandardized } \\
\text { Coefficients }\end{array}$} & \multirow{2}{*}{$\begin{array}{c}\begin{array}{c}\text { Standardized } \\
\text { Coefficien } \\
\text { ts }\end{array} \\
\text { Beta }\end{array}$} & \multirow[t]{2}{*}{$\mathrm{t}$} & \multirow[t]{2}{*}{ Sig. } \\
\hline & & $\mathrm{B}$ & Std. Error & & & \\
\hline \multirow[t]{4}{*}{1} & (Constant) & 2.480 & .727 & & 3.413 & .001 \\
\hline & $\begin{array}{l}\text { Product Quality } \\
\text { (X1) }\end{array}$ & .238 & .048 & .444 & 4.924 & .000 \\
\hline & Brand Image (X2) & .410 & .084 & .444 & 4.903 & .000 \\
\hline & Halal Labeling (X3) & .014 & .078 & .014 & .179 & .858 \\
\hline & ndent Variable: $\mathrm{Pu}$ & e Inten & tion $(\mathrm{Z})$ & & & \\
\hline
\end{tabular}

Source: primary data processed, 2021

1) Based on the partial test, the product quality has a t-count value of 4.924 , and a significance value of 0.000 . The significance value is $0.000<0.05$, then $\mathrm{H} 0$ is rejected, so it can be interpreted if the quality of the product has an influence on purchase intention.

2) Based on the partial test, the brand image has a t-count value of 4,903, and a significance value of 0.000 . The significance value is $0.000<0.05$, then $\mathrm{H} 0$ is rejected, so it can be interpreted if the brand image has an influence on purchase intention.

3) Based on the partial test, halal labeling has a t-count value of 0.179 , and a significance value of 0.858 . The significance value is $0.858>0.05$, then $\mathrm{H} 0$ is accepted, so it can be interpreted that halal labeling has no effect on purchase intention.

\subsection{Classical Asumption Test}

\subsubsection{Multicollinearity Test}




\section{$A I \overline{I E B}$ Annual International Conference \\ on Islamic Economics and Business 2021}

The multicollinearity test serves to test whether in the regression there is a perfect influence between the independent variables (Ghozali, 2013). The results of this study can be seen in the table below:

Table 6. Multicollinearity Test Results

\begin{tabular}{|c|c|c|c|c|c|c|c|c|}
\hline \multicolumn{9}{|c|}{ Coefficients $^{a}$} \\
\hline \multirow{2}{*}{\multicolumn{2}{|c|}{ Model }} & \multicolumn{2}{|c|}{$\begin{array}{c}\text { Unstandardized } \\
\text { Coefficients }\end{array}$} & \multirow{2}{*}{$\begin{array}{c}\text { Standardized } \\
\text { Coefficients }\end{array}$} & \multirow{3}{*}{$\begin{array}{c}\mathrm{t} \\
3.637\end{array}$} & \multirow{3}{*}{$\begin{array}{l}\text { Sig. } \\
.000\end{array}$} & \multicolumn{2}{|c|}{ Collinearity Statistics } \\
\hline & & B & Std. Error & & & & Tolerance & VIF \\
\hline \multirow[t]{5}{*}{1} & (Constant) & 3.228 & .887 & & & & & \\
\hline & $\begin{array}{l}\text { Product } \\
\text { Quality } \\
\text { (X1) }\end{array}$ & .159 & .062 & .247 & 2.553 & .012 & 295 & 3.395 \\
\hline & $\begin{array}{l}\text { Brand } \\
\text { Image (X2) }\end{array}$ & .349 & .108 & .314 & 3.233 & .002 & .292 & 3.423 \\
\hline & $\begin{array}{l}\text { Halal } \\
\text { Labeling } \\
\text { (X3) }\end{array}$ & .219 & .090 & .184 & 2.429 & .017 & .478 & 2.091 \\
\hline & $\begin{array}{l}\text { Purchase } \\
\text { Intention } \\
(\mathrm{Z})\end{array}$ & .259 & .118 & .215 & 2.196 & .030 & .287 & 3.479 \\
\hline
\end{tabular}

Source: primary data processed, 2021

From table 6 above, it shows that all independent variables in this study have no correlation or there is no multicollinearity, this is evidenced by the tolerance value $>0.10$ and the VIF value $<10$.

\subsubsection{Heteroscedasticity Test}

Heteroscedasticity test is a test that aims to test whether there is an inconsistent form from the first residual to further research. A good regression model is one that does not have heteroscedasticity. From the research, the results of the heteroscedasticity test can be seen as follows: 


\section{$A I \overline{I E B} \quad$ Annual International Conference \\ on Islamic Economics and Business 2021}

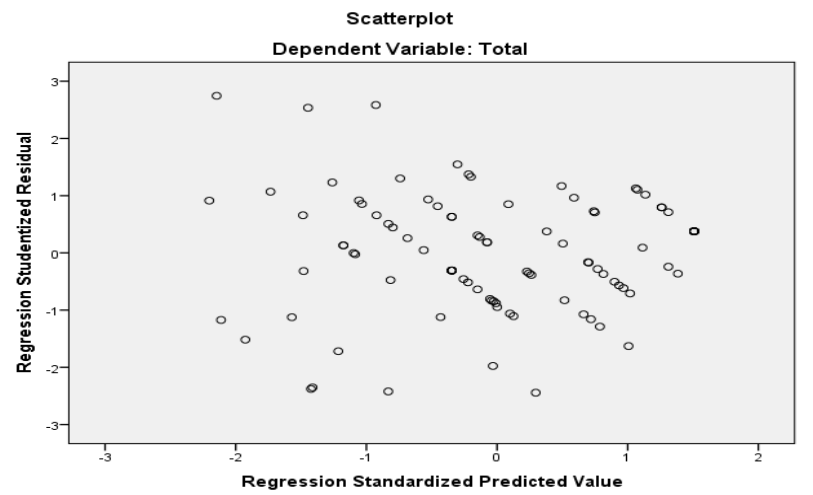

Source: primary data processed, 2021

Fig 1. Heteroscedasticity Test Results

In the graph above it looks irregular or not patterned, it can be concluded that in this study there were no symptoms of heteroscedasticity and linearity was met.

\subsubsection{Normality Test}

The normality test is a test that aims to determine whether in a regression model the residual values are normally distributed (Ghozali, 2011). Below are the results of the normality test in this study can be seen as follows:

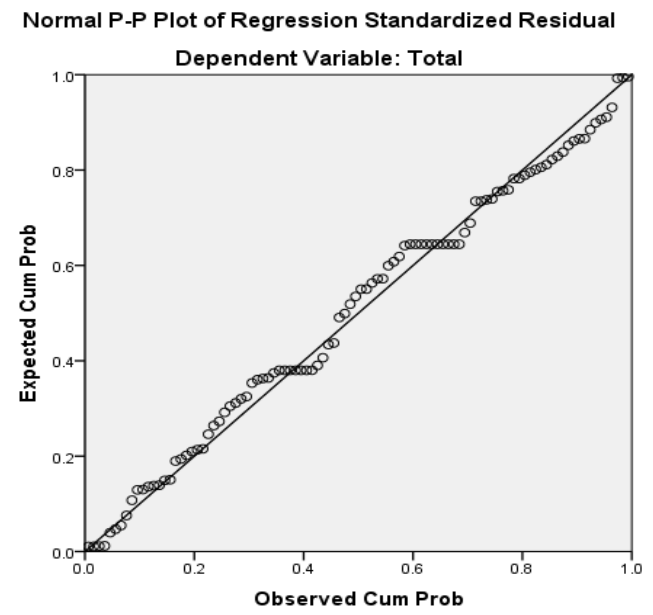

Source: primary data processed, 2021

Fig 2. Normality Test Result

In the plot graph above, it can be concluded that the existing points have spread around the diagonal line and follow the direction of the diagonal line, then this shows that if the distribution pattern in this study is normal, the conclusion is that the normality test using this plot graph meets the assumption of normality. 


\section{$A I C \overline{I E B} \quad$ Annual International Conference \\ on Islamic Economics and Business 2021}

\subsubsection{Path Analysis Test}

Path analysis is useful for measuring the relationship between 3 or more variables and is useful for determining the effect of intervening variables or what can be called mediation.

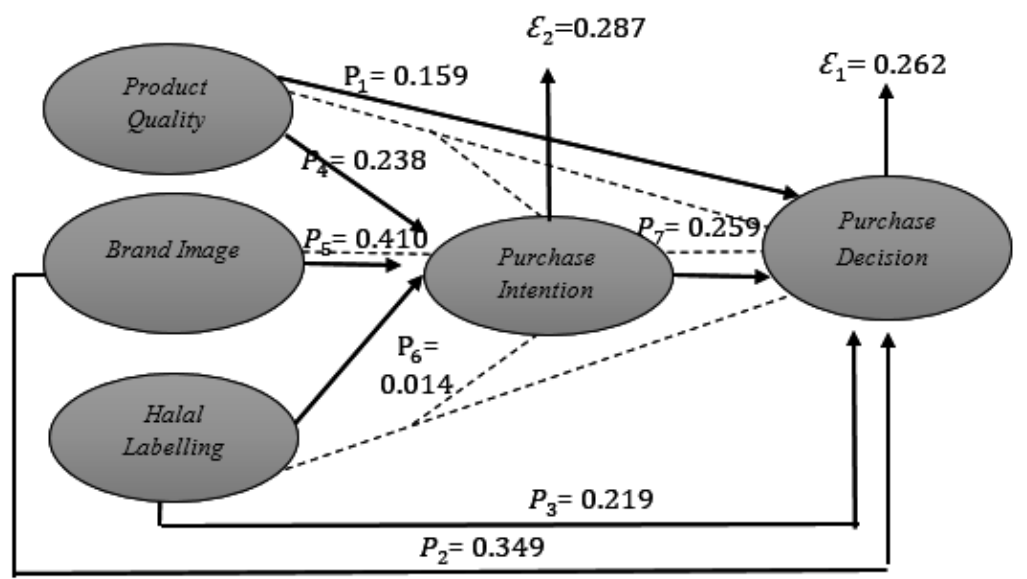

Fig 3. Path Analysis Chart

From the equation above, it is necessary to do a Sobel test to determine the effect of the mediating variable. In this research, it can be seen that:

1. The effect of product quality (X_1) on purchasing decisions (Y) mediated by purchase intention $(\mathrm{Z})$

$$
\begin{aligned}
& \mathrm{Sp}^{2} \mathrm{P}^{3}=\sqrt{\mathrm{P}^{2} \mathrm{Sp} 2^{2}+\mathrm{P}^{2} \mathrm{Sp}^{2}+\mathrm{Sp}^{2} \mathrm{Sp}^{2}} \mathrm{Sp}^{2} \mathrm{P}^{3} \\
& =\sqrt{(0.259)^{2}(0.048)^{2}+(0.238)^{2}(0.062)^{2}+(0.048)^{2}(0.062)^{2}} \\
& =\sqrt{\begin{array}{c}
(0.067081)(0.002304)+(0.0566441)(0.003844)+ \\
(0.002304)(0.003844)
\end{array}} \\
& =\sqrt{0.000154554624+0.0002177399204+0.000008856576} \\
& =\sqrt{0.0003811511204} \\
& =0.01952
\end{aligned}
$$

From the value of $\mathrm{Sp}^{2} \mathrm{P}^{3}$, the statistical $\mathrm{t}$ value of the mediation effect can be calculated using the formula (Ghozali, 2011):

$$
\begin{aligned}
& \mathrm{t} \text { count }=\frac{\mathrm{p}^{2} \mathrm{p}^{3}}{\mathrm{Sp}^{2} \mathrm{P}^{3}} \\
& =\frac{0.06164}{0.01952} \\
& =3,1578
\end{aligned}
$$

The value of $t$ count $>t$ table is $3.158>1.661$, it means that purchase intention can mediate the influence of product quality on purchasing decisions.

2. The influence of brand image (X_2) on purchasing decisions (Y) through purchase intention $(Z)$ 


\section{$A I \overline{I E B}$ Annual International Conference \\ on Islamic Economics and Business 2021}

$$
\begin{aligned}
& S p^{2} P^{3}=\sqrt{\mathrm{P}^{2} \mathrm{Sp}^{2}+\mathrm{P}^{2} \mathrm{Sp}^{2}+\mathrm{Sp}^{2} \mathrm{Sp}^{2}} \\
& =\sqrt{(0.259)^{2}(0.084)^{2}+(0.410)^{2}(0.108)^{2}+(0.081)^{2}(0.114)^{2}} \\
& =\sqrt{\begin{array}{c}
(0.067081)(0.007056)+(0.1681)(0.011664)+ \\
(0.007056)(0.011664)
\end{array}} \\
& =\sqrt{0.000473323536+0.0019607184+0.000082301184} \\
& =\sqrt{0.00251634312} \\
& =0.05016
\end{aligned}
$$

From the value of $\mathrm{Sp}^{2} \mathrm{P}^{3}$ can be calculated by the statistical $t$ value of the mediation effect with the formula (Ghozali, 2011)

$$
\begin{aligned}
& t \text { count }=\frac{\mathrm{p}^{2} \mathrm{p}^{3}}{\mathrm{Sp}^{2} \mathrm{p}^{3}} \\
& =\frac{0.10619}{0.05016} \\
& =2,1170
\end{aligned}
$$

The value at $t$ count $>t$ table is $2,1170>1.661$, it means that purchase intention can mediate the influence of brand image on purchasing decisions

3. The effect of halal labeling (X_3) on purchasing decisions (Y) through purchase intention (Z)

From the value of $\mathrm{Sp}^{2} \mathrm{P}^{3}$ can be calculated by the statistical $\mathrm{t}$ value of the mediation effect

$$
\begin{aligned}
& S p^{2} P^{3}=\sqrt{\mathrm{P}^{2} \mathrm{Sp}^{2}+\mathrm{P}^{2} \mathrm{Sp}^{2}+\mathrm{Sp} 2^{2} \mathrm{Sp}^{2}} \\
& =\sqrt{(0.259)^{2}(0.078)^{2}+(0.014)^{2}(0.090)^{2}+(0.078)^{2}(0.090)^{2}} \\
& =\sqrt{\begin{array}{c}
(0.067081)(0.006084)+(0.000196)(0.0081)+ \\
(0.006084)(0.0081)
\end{array}} \\
& =\sqrt{0.000408120804+0.0000015876+0.0000492804} \\
& =\sqrt{0.000458988804} \\
& =0,00702
\end{aligned}
$$

with the formula (Ghozali, 2011):

$$
\begin{aligned}
\mathrm{t} \text { count } & =\frac{p^{2} p^{3}}{S p^{2} P^{3}} \\
& =\frac{0.00363}{0.00702} \\
& =0,5170
\end{aligned}
$$

The value at $t$ count $=0.5170<1.661$, it means that purchase intention cannot mediate the effect of halal labeling on purchasing decisions. 


\section{References}

Ajzen, I. (1991). The Theory Of Planned Behavior. Https://Doi.Org/Https://Doi.Org/10.1016/0749-5978(91)90020-T

Akdon, \& Riduwan. (2013). Rumus dan Data Dalam Aplikasi Statistika. Alfabeta.

Alfian, I., \& Marpaung, M. (2017). Analisis pengaruh label halal, brand dan harga terhadap keputusan pembelian di Kota Medan. AT-Tawassuth: Jurnal Ekonomi Islam, 2(1), 118 141.

https://scholar.google.co.id/citations?view_op=view_citation\&hl=en\&user=Vi6QrsM AAAAJ\&citation_for_view=Vi6QrsMAAAAJ:d1gkVwhDpl0C

Alim, S. A., Mawardi, M. K., \& Bafadhal, A. (2018). Pengaruh Persepsi Label Halal Dan Kualitas Produk Terhadap Keputusan Pembelian Produk Fesyen Muslim ( Survei Pada Pelanggan Produk Zoya Muslim Di Kota Malang ). Jurnal Administrasi Bisnis Universitas Brawijaya, 62(1), 127-134.

Cannon, J. P. (2009). Pemasaran Dasar Edisi 16 Pendekatan Manajerial Global Buku 2. Salemba Empat.

Ghozali, I. (2011). Aplikasi Analisis Multivariate dengan Program IBM SPSS 19 (Edisi Kelima). Badan Penerbit Universitas Diponegoro.

Ghozali, I. (2013). Aplikasi Analisis Multivariete dengan Program IBM SPSS 21 Edisi 7 Update PLS Regresi. Universitas Diponegoro.

Immamuddin, M. (2017). Pengaruh Label Halal dan Religiusitas terhadap Keputusan Pembelian Mie Instan Mahasiswa IAIN Bukittinggi T.A 2016-2017. Journal of Economic Studies, 1(1), 34-47.

Indriyo, G. (2014). Manajemen Pemasaran. BPFE- Yogyakarta.

Juliati, S. (2019). Kisah Noviyanto, Penggagas Pabrik Keju Lokal dari Boyolali, Produk Menasional Rasa Internasional. Tribunnews.Com.

Kharisma, L., \& Hutasuhut, S. (2019). Peran Mediasi Minat Beli pada Pengaruh Brandambassador dan Kualitas Produk terhadap Keputusan Pembelian. Jurnal Niagawa, 8(3), 197-215.

Khuri, A. (2020). Analisis Pengaruh Citra Merek, Kualitas Produk, Harga dan Labelisasi Halal terhadap Keputusan Pembelian Kopi dengan Pengetahuan Sebagai Variabel Moderating (Studi Kasus pada Konsumen Kopi Berlian Sae Kemloko Temanggung).

Salatiga: Fakultas Ekonomi dan Bisnis Islam IAIN Salatiga.

Kotler, P. (2000). Prinsip- Prinsip Pemasaran Manajemen. Prenhallindo.

Kotler, P., \& Amstrong, G. (2004). Dasar-Dasar Pemasaran, Jidil II, Edisi Kesembilan. PT.Indeks.

Kotler, P., \& Amstrong, G. (2008). Manajemen Pemasaran. Terjemahan. Edisi 13. Erlangga.

Kotler, P., \& Keller, K. L. (2007). anajemen Pemasaran. Edisi 12, Jilid 1. PT. Indeks Kelompok Gramedia.

Kotler, P., \& Keller, K. L. (2009). Manajemen Pemasaran Edisi 13. Erlangga.

Kotler, P., \& Keller, K. L. (2013). Manajemen Pemasaran, Jilid Kedua. Erlangga.

Kurniawan, F. A. (2018). Pengaruh Citra Merek terhadap Keputusan Pembelian (Survei Kepada Para Siswa SMAN 15 Surabaya Kelas XII yang Menggunakan Laptop Ber Merek ASUS). Jurnal Administrasi Bisnis (JAB), 56(1), 75-81.

Latiff, A. Z. A. B., Rezai, G., Mohamed, Z., \& Amizi, A. M. (2016). Food Label's Impect Assessment on Consumer Purchasing Behavior in Malaysia. Journal of Food Products Marketing, 22(2), 137-146.

Lubis, D. I. (2017). Pengaruh Citra Merek dan Harga terhadap Keputusan Pembelian pada Sekolah Tinggi Ilmu Manajemen Sukma Medan. Jurnal Ilmu Manajemen, 5(1), 15-24. Mahyarni, M. (2013). Theory of Reasoned Action dan Theory of Planned Behavior (Sebuah Kajian Historis Tentang Perilaku). Jurnal El-Riyasah, 4(1), 13-23. 


\section{$A I \overline{I E B} \quad$ Annual International Conference \\ on Islamic Economics and Business 2021}

Nafilah, K., Widarko, A., \& Suharto, M. K. A. B. (2019). Pengaruh Kualitas Produk dan Harga terhadap Kepputusan Pembelian dan Minat Beli sebagai Variabel Intervening (Study Kasus pada Mahasiswa FEB Universitas Islam Malang Yang Mengkonsumsi Mie Instan). Jurnal Ilmiah Riset Manajemen, 8(16), 98-108.

Parmawati, R. L. (2019). Clustering Potensi Susu Sapi Perah Di Kabupaten Boyolali Menggunakan Algoritma K-Means. Jurnal Teknologi Informasi Dan Komunikasi, 1(1). Rangkuti, F. (2004). The power of brands. Gramedia Pustaka Utama.

Saputra, W. A. (2018). Pengaruh Brand Image dan Word Of Mouth terhadap Keputusan Pembelian Handphone Samsung (Studi pada Mahasiswa Jurusan Manajemen Fakultas Ekonomi dan Bisnis UNISMA). Jurnal Riset Manajemen, 7(15), 81-90.

Siregar, R. F. (2018). Faktor-faktor yang Memengaruhi Keputusan Pembelian Hijab Merek Rabbani pada CV. Rabbani Asysa Cabang Padang Sidimpuan. Fakultas Ekonomi dan Bisnis Islam IAIN Pandangsidimpuan.

Sukmaningrum, S., \& Rahardjo, M. (2017). Faktor-Faktor Yang Mempengaruhi Niat Berwirausaha Mahasiswa Menggunakan Theory Of Planned Behavior (Studi Pada Mahasiswa Pelaku Wirausaha Fakultas Ekonomika Dan Bisnis Universitas Diponegoro). Diponegoro Journal of Management, 6(3), 471-482.

Suyono, A. G., \& Sri, S. P. (2012). Pertimbangan dalam Membeli Produk Barang Maupun Jasa. Intidayu Press.

Tjiptono, F. (2008). Pemasaran Jasa Edisi Ketiga. Malang. Bayu Media Publishing.

Wicaksono, B. R. (2016). Pengaruh Kualitas Produk terhadap Keputusan Pembelian Layanan Internet yang Dimediasi oleh Minat Beli (Studi Kasus pada Mahasiswa Pengguna Provider Tri di Fakultas Ekonomi Universitas Yogyakarta). Yogyakarta.

Widarjo, W. S., Sari, R. Y. H. K., \& Cahyono, E. (2014). Eksplorasi Niat Berwirausaha pada Perajin Batik di Kota Surakarta: Anteseden dan Peran Entrepreneurship Education Programme (Eep) sebagai Variabel Pemoderasi. Riset Manajemen Dan Akuntansi STIE Atma Bhakti, 5(10), 86-106.

Yadewani, D., \& Wijaya, R. (2017). Pengaruh e-Commerce terhadap minat berwirausaha. Journal RESTI (Rekayasa Sistem Dan Eknologi Informasi), 1(1), 1-64. 